NOTE

\title{
El Niño-associated disturbance to coral reefs and post disturbance mortality by Acanthaster planci
}

\author{
Peter W. Glynn \\ Division of Biology and Living Resources, Rosenstiel School of Marine and Atmospheric Science, 4600 Rickenbacker Causeway, Miami, Florida \\ 33149 , USA
}

\begin{abstract}
Coral reefs in the tropical eastern Pacific region experienced catastrophic coral mortality during the severe 1982/1983 El Nin̄o event. Pocillopora spp., the dominant scleractinian reef-building corals, were most seriously affected, resulting in large tracts ( 0.1 to 1 ha) of dead reef surface in Costa Rica, Panamá, Colombia, and the Galápagos Islands, Ecuador. A sea star Acanthaster planci is now entering centrally-located reef areas in Panamá corals and is feeding on large, massive corals formerly surrounded and protected by live Pocillopora corals and their symbiotic crustacean guards. This note outlines the effects of El Nino-related differential coral mortality and subsequent mortality resulting from the elimination of a protective biotic barrier The ages of corals killed during the initial physical disturbance, and later by predation, allow an estimate of the period of uninterrupted reef growth, i.e. the minimum number of years since an earlier, major El Niño event: about 190 yr on the basis of present evidence.
\end{abstract}

Warm tropical waters have traditionally been regarded as beneficial to coral reef development and growth (Dana 1843, Wells 1957, Kinsman 1964, Rosen 1971, Stehli \& Wells 1971). Occasionally, however, intense natural warming of reef waters has resulted in localized, reef-building coral mortality (Shinn 1966, Jaap 1979, Yamazato 1981). The course of such events has typically involved a stress to the coral and its symbiotic algae (zooxanthellae) with the loss of zooxanthellae ('bleaching'), and subsequent recovery or death of the host coral colony. The El Niño event of $1982 / 83$, regarded as the strongest this century (Halpern 1983, Kerr 1983), accompanied widespread coral mortality in the equatorial eastern Pacific region in 1983 (Glynn 1983a, Lessios et al. 1983, Glynn 1984a). The abnormally high sea surface temperatures (mean values 30 to $31^{\circ} \mathrm{C}$ ), their duration (5 to $6 \mathrm{mo}$, Glynn 1984a), and depth of isotherm penetration (nearly $100 \mathrm{~m}$ deeper in some areas than in previous years, Rebert et al. 1983), were probably in large part responsible for the disturbance.

Coral mortality was generally highest among species exhibiting the most rapid skeletal growth, e.g.
Pocillopora spp. and Millepora spp. (hydrocorals). Several surviving coral species, previously protected from coral-eating sea stars because of their location on the reef, were exposed to predation following the El Niñoassociated catastrophe. These mortality events were observed on coral reefs located off the Pacific coast of Panamá in the Gulf of Chiriquí, at Uva Island $\left(7^{\circ} 48^{\prime} 46^{\prime \prime} \mathrm{N} ; 81^{\circ} 45^{\prime} 35^{\prime \prime} \mathrm{W}\right)$, Contreras Islands, and at an

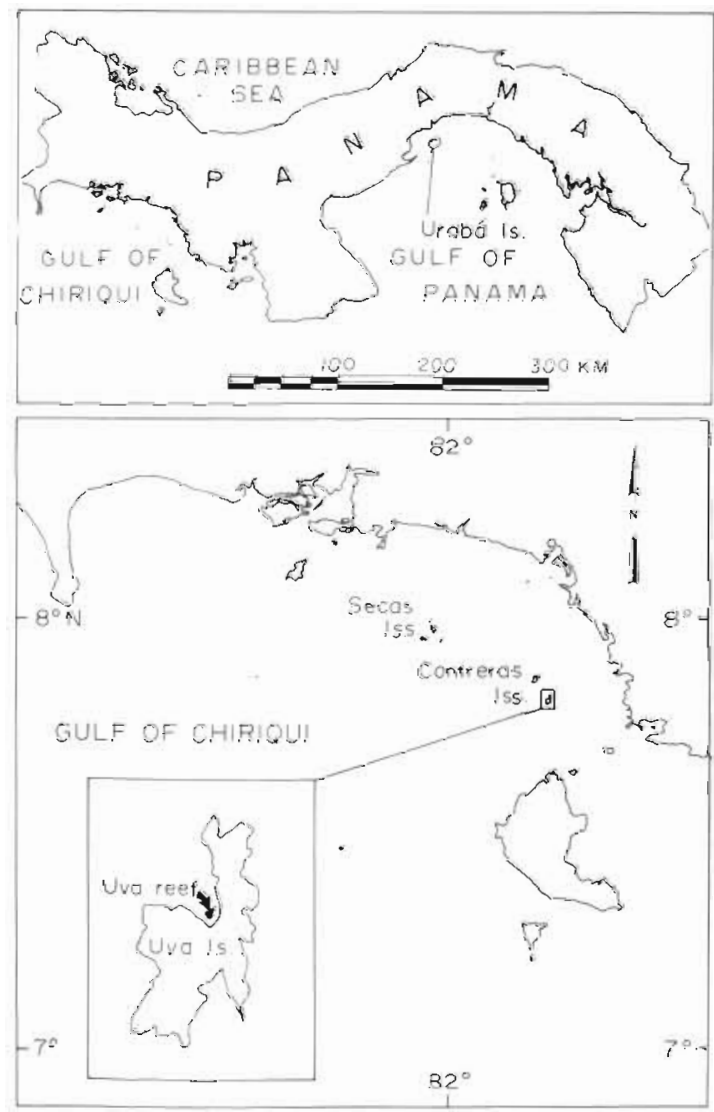

Fig. 1. Study areas showing locations of Uva Island and Secas Islands, Gulf of Chiriquí, and Urabá Island, Gulf of Panamá 
un-named island $\left(7^{\circ} 51^{\prime} 18^{\prime \prime} \mathrm{N}_{i} 82^{\circ} 00^{\prime} 45^{\circ} \prime \mathrm{W}\right)$, Secas Islands (Fig. 1).

Branching pocilloporid corals are the chief reef-builders in the eastern Pacific (Glynn et al. 1972, Porter 1972a, b, 1974, Glynn 1976, Glynn \& Wellington 1983). Pocillopora damicornis (Linnaeus) is usually the most abundant species with $P$. elegans Dana also present on most reefs. Less than 10 other coral species of massive, platy and nodular growth forms contribute to eastern Pacific reef frameworks. In areas where the sea star corallivore Acanthaster planci (Linnaeus) is present, these nonpocilloporid species are often less abundant and are generally smaller in size compared with corals in reef areas without this corallivore (Glynn et al. 1982, Glynn \& Wellington 1983, Glynn et al. 1983). Nonpocilloporid corals present on the deep ( 8 to $10 \mathrm{~m})$ edges of reefs are frequently attacked and eaten by A. planci (Glynn 1973, 1976). A. planci has demonstrated a consistent feeding preference for several of the nonpocilloporid coral species in Panamá (Glynn 1976,

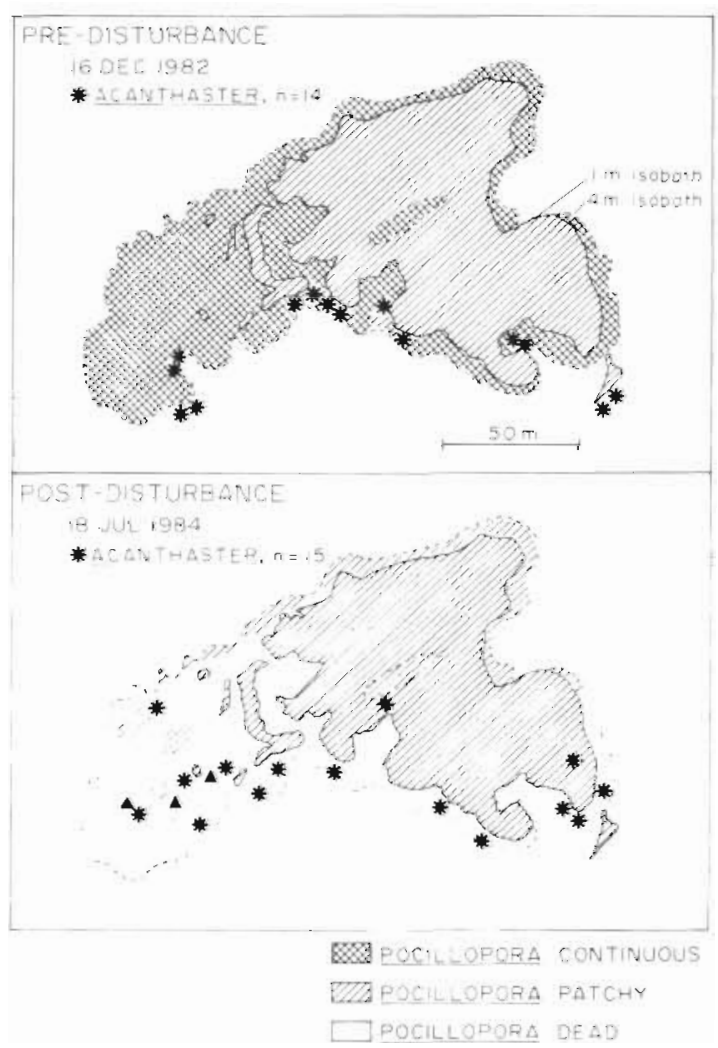

Fig. 2. Plan views of Uva Island patch reef showing the distribution and relative abundance of live Pocillopora spp. corals before and after the 1983 coral mortality event. Continuous stands of Pocillopora, from 3 to $8 \mathrm{~m}$ depth, were killed; 1 and $4 \mathrm{~m}$ isobaths indicated relative to the MLWS tidal datum. Abundances and locations of Acanthaster planci also shown. The 3 triangles in the northern reef zone show the locations of large massive corals attacked by $A$. planci after March 1983. Major features of reef maps according to survey conducted in 1972 (Glynn 1973)
Glynn et al. 1983). The principal nonpocilloporid corals are Gardineroseris planulata (Dana), Pavona clavus Dana, Pavona gigantea Verrill, and Pavona varians Verrill. Since 1970 all large colonies of G. planulata $(\mathrm{n}=74$ colonies with maximum diameters $\geq 0.25 \mathrm{~m}$ ) have been attacked by $A$. planci in these deep reef habitats, resulting in total to near-total colony death. All of these colonies have undergone erosion and collapse or have served as substrata for other coral settlement (e.g. Pavona varians and Pocillopora elegans), but have not shown any significant regeneration.

On parts of reefs where Pocillopora spp. are abundant, especially where these corals form encircling, continuous, live tracts, nonpocilloporid species are often present and sometimes reach large sizes. The occurrence of nonpocilloporid corals among dense stands of Pocillopora spp. seems to be due to a refuge effect, wherein the latter prevent the entry of foraging Acanthaster planci into centrally-located (core) reef areas. A. planci does not move over continuous stands of Pocillopora spp. because of the coral's nematocyst defenses (Barnes et al. 1970) and possession of crustacean guards (Trapezia and Alpheus) which attack and repel sea stars (Glynn 1976, 1983b). The catastrophic coral mortality accompanying the 1982/83 El Niño in the eastern Pacific resulted in the death of large tracts of Pocillopora spp. and their crustacean guard symbionts. This nullified the protective effect of Pocillopora spp., thus allowing $A$. planci access to reef areas with favored coral prey. Compare the pre- and postdisturbance patterns of Pocillopora abundance and the corresponding location of foraging A. planci in Fig. 2. The numbers of crustacean guards per coral colony and the frequency of aggressive responses toward A. planci declined significantly during the period of coral 'bleaching', morbidity and death (Fig. 3). The decline in guard density and defensive behavior was probably due to the deteriorating condition of host corals, and not a direct result of the general sea warming. Coral mucus and entrapped detritus represent the normal food source for these obligate crustacean symbionts (Knudsen 1967, Patton 1974, 1976, Castro 1976, Glynn 1983c), and mucus release declined significantly in the affected corals (Fig. 3A). Lipid levels also declined in stressed host corals and symbiotic crabs, suggesting that the crustacean guards were affected by food deprivation (Glynn et al. 1985).

One group of 22 colonies of the massive coral Gardineroseris planulata, previously (before April 1983) encircled by live Pocillopora spp., had shown no evidence of predation by Acanthaster planci since 1972, when it was first observed. By 30 October 1983, about 6 mo after the near-total death (up to $95 \%$ ) of surrounding Pocilloporaspp. (Glynn 1984a), A. planci had entered the reef core and was feeding on the largest of 
Fig. 3. Decline in mucus release (A), crustacean guard density (B) and crustacean defense (C) in host colonies of the coral Pocillopora damicornis during the 1983 mortality event in Panamá. Crustacean guards included 4 species of the xanthid crab Trapezia, and the alpheid shrimp Alpheus lottini. Coral condition: $N$, normal-appearing with full brown pigmentation; PB, partially 'bleached'; FB, fully 'bleached'; D, dead. Median values, 0.95 confidence limits of medians, and number of colonies sampled (in parentheses) shown for each condition. Kruskal-Wallis significance levels indicated in each plot; horizontal lines along abscissas join statistically equal median values (multiple comparison procedure, $\alpha=$ 0.15 ). Mucus release was determined by 'milking' (inverting and shaking gently) corals, then collecting the crude mucus and determining its volume (Glynn 1983b, c); Urabá Island, Gulf of Panamá $\left(8^{\circ} 47^{\prime} 03^{\prime \prime} \mathrm{N} ; 79^{\circ} 32^{\prime} 22^{\prime \prime} \mathrm{W}\right), 14$ June 1983; Md (median) colony diameter $=9 \mathrm{~cm}$ (8 to $10 \mathrm{~cm}, 0.95 \mathrm{conf}$. lim. of $\mathrm{Md}$ ). Crustacean densities are total number of crab (Trapezia spp.) and shrimp (Alpheus lottini Guerin) guards found in individual colonies that were bagged in situ, dislodged and processed in the laboratory (Glynn 1976); Uva and Secas study reefs, 23 to 24 June 1983; Md colony diameter = $14 \mathrm{~cm}(14$ to $15 \mathrm{~cm})$. Simulated feeding attacks with live Acanthaster planci (disc diameters $=13$ to $16 \mathrm{~cm}$ ) were used to quantify the aggressive defensive responses of coral crab and shrimp guards (Glynn 1983b); Uva study reef, 27 to 28 April 1983; Md colony diameter $=27 \mathrm{~cm}(25$ to $29 \mathrm{~cm})$. Colony size was similar ( $\mathrm{p}>0.05$, Kruskal-Wallis test) among treatments (coral condition) for each of the 3 tests

the colonies in this group. Approximately $0.20 \mathrm{~m}^{2}$ of the surface of the largest colony $(10 \%$ of the total live tissues) had been killed by October, and $0.40 \mathrm{~m}^{2}(20 \%)$ by 18 July 1984 . Up to $95 \%$ of the live surfaces of other colonies in this group had also been killed by $A$. planci by mid July 1984. The feeding scars caused by $A$. planci were readily distinguishable from the upper summits of colonies that were discolored and damaged during the El Niño event. From October 1983 to July 1984, A. planci was feeding on other groups of G. planulata and on platy and encrusting colonies of Pavona varians in other reef core areas that were also formerly surrounded and protected by live Pocillopora spp. (Fig. 4).

Cores up to $254 \mathrm{~cm}$ in length were drilled from Gardineroseris planulata, cut along the growth axis to
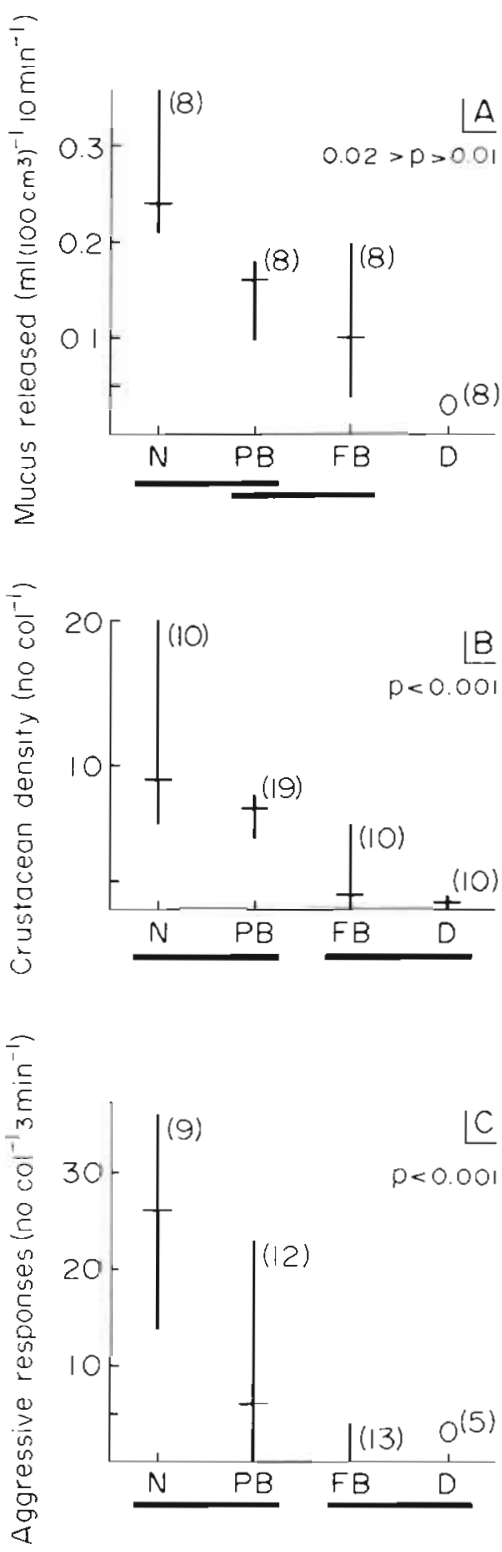

$4 \mathrm{~mm}$ thickness, and X-rayed for density band and growth rate analyses (Buddemeier 1978, Macintyre 1978). Individual corallites could be traced intact along the growth axes. Since most colonies of $G$. planulata were nearly perfectly symmetrical (hemispherical mounds) and exhibited continuous skeletal growth, it is unlikely that they have undergone significant colony death, as observed after 1983, since their recruitment onto the reef. Thus, the oldest colony, whose 2 cores (232 and $254 \mathrm{~cm}$ length) showed no major discontinuities, should provide an estimate of the time that this group of nonpocilloporid corals has been encircled by a living, protective belt of Pocillopora spp.

This means of prey protection via a biotic refugium assumes that Acanthaster planci has been an important 


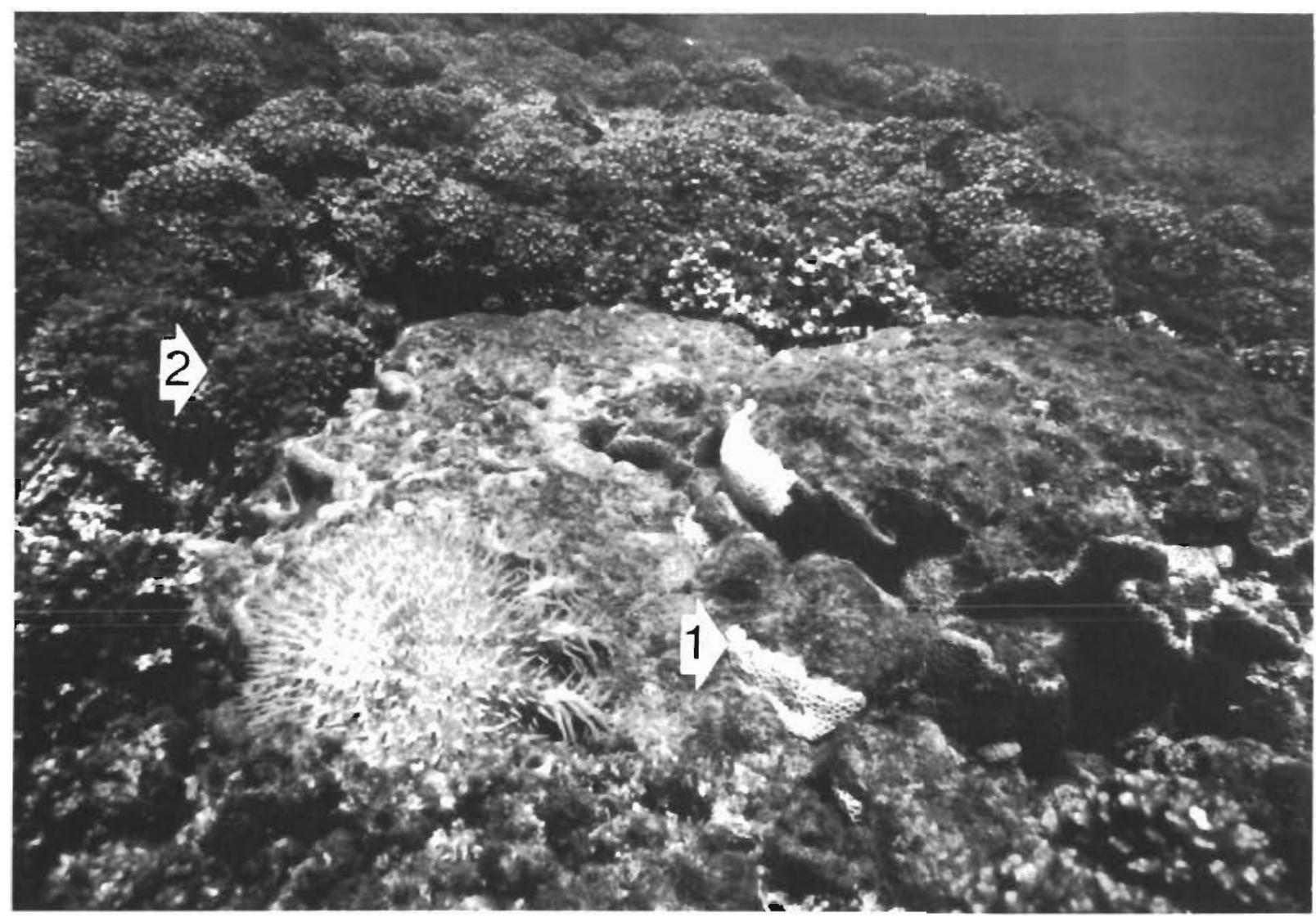

Fig. 4. Acanthaster planci feeding on colony of Gardineroseris planulata formerly (before March 1983) encircled and protected by dense stands of live Pocillopora spp. coral (22 Jun 1984, $5 \mathrm{~m}$ depth). Arrows 1 and 2 point respectively to a dead patch of G. planulata killed by $A$. planci (left, same sea star feeding on another patch on same colony, maximum diameter arm tip-arm tip $\simeq 30 \mathrm{~cm}$ ), and dead Pocillopora over which sea stars have moved to reach reef core areas

predator on the Uva reef during this period. The first documented record of $A$. planci in the eastern Pacific is from La Paz, Mexico, reported in 1869 (Verrill 1869, Madsen 1955). Relatively stable population sizes of A. planci, observed in Panamá since 1971 (Glynn 1982, $1984 \mathrm{~b}$ ), are also assumed. The largest, and presumably oldest colony was $254 \mathrm{~cm}$ in height, had a mean annual growth rate of $1.3 \mathrm{~cm}$, and grew continuously for about 192 yr (Table 1). While some skeletal growth irregularities were found, major growth hiatuses and corroded surfaces due to partial mortality or waxing and waning growth were not observed as in some corals (Hughes \& Jackson 1980, Jackson 1983). A large colony of Pavona gigantea grew continuously for $122 \mathrm{yr}$, and the thickest vertical exposures of the pocilloporid reef frame indicated uninterrupted growth for $41 \mathrm{yr}$ (Uva reef) and $73 \mathrm{yr}$ (Secas reef) Longer mean growth periods are indicated for pocilloporid frameworks that were excavated and aged by C-14 dating (130 to 140 yr, Table 1), but these are net accumulation rates, usually involving different coral colonies, crustose coralline algae, etc., and represent combined growth and erosional events.
Another line of evidence from the core drilling indicates that Acanthaster planci did inhabit the Uva reef before the largest colony of Gardineroseris planulata was recruited onto the reef. After the oldest section of the colony was cored and retrieved, the drill hole was re-entered and underlying sediments were obtained from $302 \mathrm{~cm}$ depth, i.e. at $48 \mathrm{~cm}$ beneath the original colony attachment site. These sediments were examined for $A$. planci skeletal remains, after Frankel's (1977) method, and one skeletal element was found in $1.25 \mathrm{~kg}$ (dry weight) of sample analysed. This result indicates that $A$. planci was present in the area 200 yr ago. More extensive sampling (Glynn unpubl.) at 3 sites on the deep reef edge revealed the presence of A. planci skeletal elements in 9 of 16 samples collected from the surface to $150 \mathrm{~cm}$ deep in the carbonate sediments. Although the ages of these skeletal elements are presently unknown, it seems probable that $A$. planci has been present on the Uva reef during at least the last $200 \mathrm{yr}$

The high growth rate of Pocillopora spp. compared with massive corals (about 3 times as fast) is probably one of the chief reasons why the former are predomi- 
Table 1. Estimated periods of maximum uninterrupted coral colony growth and net coral reef frame growth, Gulf of Chiriquí, Panamá

\begin{tabular}{|c|c|c|c|}
\hline Sample & $\begin{array}{l}\text { Maximum vertical } \\
\text { length along } \\
\text { growth axis }(\mathrm{cm})\end{array}$ & $\begin{array}{l}\text { Growth } \\
\text { rate } \\
\left(\mathrm{cm} \mathrm{yr}^{-1}\right)\end{array}$ & $\begin{array}{l}\text { Period of } \\
\text { continuous } \\
\text { growth (yr) }\end{array}$ \\
\hline $\begin{array}{l}\text { Gardineroseris planulata, } \\
\text { colony, Uva study reef, } \\
30 \text { Oct } 1983\end{array}$ & 254 & $\begin{array}{c}1.32 \\
(1.2-1.4)^{a}\end{array}$ & $\begin{array}{c}192 \\
(185-204)\end{array}$ \\
\hline $\begin{array}{l}\text { Pavona gigantea, colony, } \\
\text { Secas Islands }\left(7^{\circ} 57^{\prime} 50^{\prime \prime} \mathrm{N},\right. \\
\left.82^{\circ} 01^{\prime} 40^{\prime \prime} \mathrm{W}\right), 14 \operatorname{Dec} 1980\end{array}$ & 110 & $\begin{array}{c}0.90 \\
(0.8-1.1)^{b}\end{array}$ & $\begin{array}{c}122 \\
(100-138)\end{array}$ \\
\hline $\begin{array}{l}\text { Pocillopora damicornis, } \\
\text { exposed reef frame, Uva } \\
\text { study reef, } 30 \text { Oct } 1983\end{array}$ & 160 & $\begin{array}{c}3.90 \\
(3.4-4.3)^{c}\end{array}$ & $\begin{array}{c}41 \\
(37-47)\end{array}$ \\
\hline $\begin{array}{l}\text { Pocillopora damicornis, } \\
\text { exposed reef frame, Secas } \\
\text { study reef, } 31 \text { Oct } 1983\end{array}$ & 285 & $\begin{array}{c}3.90 \\
(3.4-4.3)^{c}\end{array}$ & $\begin{array}{c}73 \\
(66-84)\end{array}$ \\
\hline $\begin{array}{l}\text { Pocillopora damicornis, } \\
\text { excavated reef frame, Secas } \\
\text { study reef, } 25 \text { Mar } 1971\end{array}$ & 270 & $\begin{array}{c}2.08 \\
(1.3-6.0)^{\mathrm{d}}\end{array}$ & $\begin{array}{c}130 \\
(45-215)\end{array}$ \\
\hline $\begin{array}{l}\text { Pocillopora damicornis, } \\
\text { excavated reef frame, Secas } \\
\text { study reef, } 23 \text { Sep } 1972\end{array}$ & 200 & $\begin{array}{c}1.43 \\
(1.0-2.5)^{d}\end{array}$ & $\begin{array}{c}140 \\
(80-200)\end{array}$ \\
\hline \multicolumn{4}{|c|}{$\begin{array}{l}\text { a Range of mean growth rates from } 3 \text { transects (colony surface to } 50 \mathrm{~cm} \text { deep in colony) from same colony } \\
\text { b Range of median colony growth ( } \mathrm{N}=15 \text { colonies, Glynn et al. } 1983 \text { ) } \\
\text { c } 0.95 \text { confidence limits of mean coral growth (Glynn } 1977 \text {, Glynn \& Macintyre 1977) } \\
\text { d Mean } \pm 1 \mathrm{SD} \text {, based on C-14 date (Glynn } 1977 \text {, Glynn \& Macintyre 1977) }\end{array}$} \\
\hline
\end{tabular}

nant on eastern Pacific reefs. Nonpocilloporid species escape attacks from Acanthaster planci among dense stands of Pocillopora spp., but this kind of protection is usually only temporary. Sooner or later, perhaps on a time scale of 100 or few 100s of years, Pocillopora spp. will overtop and dominate reef surfaces. Severe El Niño disturbances that differentially kill branching corals would tend to slow down the potential domination by Pocillopora. On a shorter time-scale (10s of years), other conditions may also impede the growth of Pocillopora, e.g. disturbances differentially affecting but not necessarily killing ramose corals (Bak \& Luckhurst 1980, Highsmith 1982, Hughes \& Jackson 1985) or minor El Niño warming spells that limit growth while still leaving protective coral stands intact. If the death of branching corals is too extensive, however, this protective barrier would be eliminated, thus allowing the entry of sea star corallivores into massive coral refugia.

I have also observed that massive corals with associated fishes, sharks, and spiny lobsters that use the eroded coral bases for shelter often have a bare zone (halo) of coarse sediment surrounding the colony. The persistence of this zone, probably in large part aided by the associated animals seeking shelter, would prevent the establishment, encroachment and overgrowth of branching corals immediately adjacent to massive colonies.

In summary, present indirect evidence suggests that coral and reef growth have proceeded continuously in Panamá during the past $190 \mathrm{yr}$. A severe El Niño, of the magnitude of the 1982/83 disturbance, has probably not visited Panamá over this period.

Acknowledgements. I thank J. H. Hudson, S. L. Gilchrist, M. Perez and A. Velarde for help with this study, and S. L. Gilchrist, J. H. Hudson, P. Lutz, R. H. Richmond, A. SzmantFroelich, M. J. Tegner, and G. M. Wellington for comments on the manuscript. Research was supported by the Scholarly Studies Program, grant 1234S104, Smithsonian Institution, and by U.S. National Science Foundation grant OCE 8415615 .

\section{LITERATURE CITED}

Bak, R. P. M., Luckhurst, B. E. (1980). Constancy and change in coral reef habitats along depth gradients at Curaçao. Oecologia (Berl.) 47: 145-155

Barnes, D. J., Brauer, R. W., Jordan, M. R. (1970). Locomotory response of Acanthaster planci to various species of coral. Nature, Lond. 228: 342-344

Buddemeier, R. W. (1978). Coral growth: retrospective analysis. In: Stoddart, D. R., Johannes, R. E. (ed.) Coral reefs: research methods. Monogr Oceanogr. Method. 5, UNESCO, Paris, p. 551-571 
Castro, P. (1976). Brachyuran crabs symbiotic with scleractinian corals: a review of their biology. Micronesica 12. $99-110$

Dana, J. D. (1843). On the temperature limiting the distribution of corals. Am. J. Sci. \& Arts 45: 130-131

Dana, T. F. (1975). Development of contemporary eastern Pacific coral reefs. Mar Biol. 33: 355-374

Frankel, E. (1977). Previous Acanthaster aggregations in the Great Barrier Reef. Proc. 3rd Int. Coral Reef Symp. 1: 201-208

Glynn, P. W (1973). Acanthaster effect on coral reef growth in Panamá. Science 180: 504-506

Glynn, P. W. (1976). Some physical and biological determinants of coral community structure in the eastern Pacific. Ecol. Monogr. 46: 431-456

Glynn, P. W. (1977). Coral growth in upwelling and nonupwelling areas off the Pacific coast of Panamá. J. mar. Res. 35: $567-585$

Glynn, P. W. (1982). Acanthaster population regulation by a shrimp and a worm. Proc. 4th Int. Coral Reef Symp. 2: $607-612$

Glynn, P. W (1983a). Extensive 'bleaching' and death of reef corals on the Pacific coast of Panamá. Environ. Conserv 10: 149-154

Glynn, P. W (1983b). Crustacean symbionts and the defense of corals: coevolution on the reef? In: Nitecki, M. H. (ed.) Coevolution. Univ. of Chicago Press, Chicago, p. 111-178

Glynn, P. W. (1983c). Increased survivorship in corals harboring crustacean symbionts. Mar. Biol. Lett. 4: 105-111

Glynn, P. W. (1984a). Widespread coral mortality and the 1982-83 El Niño warming event. Environ. Conserv. 11: $133-146$

Glynn, P. W (1984b). An amphinomid worm predator of the crown-of-thorns sea star and general predation on asteroids in eastern and western Pacific coral reefs. Bull. mar. Sci. 35: 54-71

Glynn, P. W. Macintyre, I. G. (1977). Growth rate and age of coral reefs on the Pacific coast of Panamá. Proc. 3rd Int. Coral Reef Symp. 2: 251-259

Glynn, P. W., WeIlington, G. M. (1983). Corals and coral reefs of the Galápagos Islands. Univ. of California Press, Berkeley

Glynn, P. W., Druffel, E. M., Dunbar, R. B. (1983). A dead Central American coral-reef tract: possible link with the Little Ice Age. J. mar Res. 41: 605-637

Glynn, P. W., Perez, M., Gilchrist, S. L. (1985). Lipid decline in stressed corals and their crustacean symbionts. Biol. Bull. mar biol. Lab., Woods Hole 168: 276-284

Glynn, P. W., Stewart, R. H., McCosker, J. E. (1972). Pacific coral reefs of Panamá: structure, distribution and predators. Geol. Rundsch. 61: 483-519

Glynn, P. W., Prahl, H. von, Guhl, F. (1982). Coral reefs of Gorgona Island, Colombia, with special reference to corallivores and their influence on community structure and reef development. An. Inst. Inv. Mar Punta de Betin 12: $185-214$

Halpern, D. (1983). Editor's note. Trop. Ocean.-Atmos. Newslett. 21. 1

Highsmith, R. C. (1982). Reproduction by fragmentation in corals. Mar. Ecol. Prog. Ser 7: 207-226

Hughes, T. P., Jackson, J. B. C. (1980). Do corals lie about their age? Some demographic consequences of partial mortality, fission, and fusion. Science 209: 713-715

Hughes, T P., Jackson, J. B. C. (1985). Population dynamics and life histories of foliaceous corals. Ecol. Monogr 55 $141-166$
Jaap, W C. (1979). Observations on zooxanthellae expulsion at Middle Sambo Reef, Florida Keys. Bull. mar. Sci. 29: $414-422$

Jackson, J. B. C. (1983). Biological determinants of present and past sessile animal distributions. In: Tevesz, M. J. S., McCall, P. L. (ed.) Biotic interactions in recent and fossil benthic communities. PIenum Pub. Corp., New York, p. 39-120

Kerr, R. A. (1983). Fading El Niño broadening scientists view. Science 221: 940-941

Kinsman, D. J. J. (1964). Reef coral tolerance of high temperatures and salinities. Nature, Lond. 202: 1280-1282

Knudsen, J. W (1967). Trapezia and Tetralia (Decapoda, Brachyura, Xanthidae) as obligate ectoparasites of pocilloporid and acroporid corals. Pacif. Sci. 21: 50-57

Lessios, H. A., Glynn, P. W., Robertson, D. R. (1983). Mass mortalities of coral-reef organisms. Science 222: 715

Madsen, F. J. (1955). A note on the sea-star genus Acanthaster. Vidensk. Meddr dansk naturh. Foren. 117: 179-192

Macintyre, I. G. (1978). A hand-operated submersible drill for coring reef substrata. In: Stoddart, D. R., Johannes, R. E. (ed.) Coral reefs: research methods. Monogr. Oceanogr. Method. 5, UNESCO, Paris, p. 75-80

Patton, W. K. (1974). Community structure among the animals inhabiting the coral Pocillopora damicornis at Heron Island, Australia. In: Vernberg, W. B. (ed.) Symbiosis in the sea. Univ. of South Carolina Press, Columbia, South Carolina, p. 219-243

Patton, W. K. (1976). Animal associates of living corals. In: Jones, O. A., Endean, R. (ed.) Biology and geology of coral reefs. Vol. 3, Biol. 2, Academic Press, New York, p. 1-36

Porter, J. W (1972a). Ecology and species diversity of coral reefs on opposite sides of the Isthmus of Panamá. In: Jones, M. L. (ed.) The Panamic biota: some observations prior to a sea-level canal. Bull. Biol. Soc. Wash. No. 2 , Washington D. C., p. 89-116

Porter, J. W. (1972b). Predation by Acanthaster and its effect on coral species diversity. Am. Nat. 106: 487-492

Porter, J. W. (1974). Community structure of coral reefs on opposite sides of the Isthmus of Panama. Science 186: 543-545

Rebert, J.-P., Donguy, J.-R., Eldin, G., Morliere, A. (1983). Thermal fluctuations in the equatorial Pacific in relation to the 1982-1983 warm event. Trop. Ocean.-Atmos. Newslett. 21: 7-8

Rosen, B. R. (1971). The distribution of reef-coral genera in the Indian Ocean. In: Stoddart, D. R., Yonge, M. (ed.) Regional variation in Indian Ocean coral reefs. Symp. Zool. Soc. Lond., No. 28, Academic Press, London \& New York, p. 263-299

Shinn, E. A. (1966). Coral growth-rate, an environmental indicator. J. Paleont. 40: 233-240

Stehli, F. G., Wells, J. W. (1971). Diversity and age patterns in hermatypic corals. Syst. Zool. 20: 115-126

Verrill, A. E. (1869). On some new and imperfectly known echinoderms and corals. Proc. Boston Soc. Nat. Hist. 12: 381-396

Wells, J. W (1957). Corals. In: Hedgpeth, J. W. (ed.) Treatise on marine ecology and paleoecology. Ecology, Mem. 67. Geol. Soc. Am., New York, p. 1087-1104

Yamazato, K. (1981). A note on the expulsion of zooxanthellae during summer, 1980, by the Okinawan reef-building corals Sesoko Mar Sci. Lab. Tech. Rep. 8: 9-18 